\title{
Journal of the Royal Society of New Zealand
}

\section{Inhibition of enzymes important for Alzheimer's disease by antioxidant extracts prepared from 15 New Zealand medicinal trees and bushes}

\section{Hafiz Majid \& Filipa V. M. Silva}

To cite this article: Hafiz Majid \& Filipa V. M. Silva (2020) Inhibition of enzymes important for Alzheimer's disease by antioxidant extracts prepared from 15 New Zealand medicinal trees and bushes, Journal of the Royal Society of New Zealand, 50:4, 538-551, DOI: 10.1080/03036758.2020.1741403

To link to this article: https://doi.org/10.1080/03036758.2020.1741403

Published online: 22 Mar 2020.

Submit your article to this journal $₫$

Џ Article views: 73

Q View related articles ¿

View Crossmark data \lceil 


\title{
Inhibition of enzymes important for Alzheimer's disease by antioxidant extracts prepared from 15 New Zealand medicinal trees and bushes
}

\author{
Hafiz Majid (D) a,b and Filipa V. M. Silva (iD) ${ }^{a, c}$ \\ ${ }^{a}$ Chemical and Materials Engineering Department, University of Auckland, Auckland, New Zealand; ${ }^{b}$ Faculty of \\ Science and Natural Resources, Universiti Malaysia Sabah, Sabah, Malaysia; 'LEAF, School of Agriculture, \\ University of Lisbon, Lisboa, Portugal
}

\begin{abstract}
Alzheimer's disease is characterised by progressive mental deterioration, related to ageing and senility. Thirty methanol and ethyl acetate extracts from 15 native New Zealand trees and bushes were produced and tested for the inhibition of three enzymes related to neurotransmission: acetylcholinesterase $(\mathrm{AChE})$, butyrylcholinesterase (BChE) and beta-secretase (BACE). In addition the $\mathrm{IC}_{50}$ for the antioxidant potential of the extracts was determined. Weinmannia racemosa and Kunzea ericoides were effective inhibitors of $A C h E-B C h E$ and beta-secretase, respectively. The $\mathrm{IC}_{50}$ for $W$. racemosa extracts against $\mathrm{AChE}$ and $\mathrm{BChE}$ ranged between $8.09 \mu \mathrm{g} / \mathrm{mL}$ and $37.07 \mu \mathrm{g} / \mathrm{mL}$. The ethyl acetate extract of Schefflera digitata was also an effective inhibitor of $\mathrm{BChE}\left(\mathrm{IC}_{50}=\right.$ $25.38 \mu \mathrm{g} / \mathrm{mL}$ ). $K$. ericoides $\mathrm{IC}_{50}$ for beta-secretase were $29.05 \mu \mathrm{g} / \mathrm{mL}$ and $36.40 \mu \mathrm{g} / \mathrm{ml}$. The highest radical scavenging activity (RSA) was detected in the methanol extract of Aristotelia serrata $\left(\mathrm{IC}_{50}=\right.$ $2.34 \mu \mathrm{g} / \mathrm{mL}$ ), followed by both extracts of Hebe stricta and $W$. racemosa, and last the methanol extracts of $K$. ericoides and Pomaderris kumeraho, which presented higher RSA than the reference antioxidant $\left(\mathrm{IC}_{50}<12.0 \mu \mathrm{g} / \mathrm{mL}\right)$. W. racemosa showed inhibitory activity against $\mathrm{AChE}$ and $\mathrm{BChE}$ enzymes and antioxidant activity, which suggests these extracts may have potential for application in patients suffering from Alzheimer's disease and other dementias.
\end{abstract}

\section{ARTICLE HISTORY}

Received 19 December 2019

Accepted 9 March 2020

\section{KEYWORDS}

Bioactive; acetylcholinesterase; butyrylcholinesterase; betasecretase; radical scavenging activity; dementia

\section{Introduction}

Alzheimer's disease $(\mathrm{AD})$ is a type of dementia which affects nearly 50 million people worldwide (Gaudreault and Mousseau 2019). It is estimated that 3\% of people aged 6574 years are affected, while $47.2 \%$ of patients over 85 years old are affected. Based on statistics and demographic trends, it is likely that the number of $\mathrm{AD}$ patients will exponentially increase to an estimated 114 million by 2050 (Adewusi and Steenkamp 2011; Gaudreault and Mousseau 2019). The actual cause of AD is still unclear. Most researchers believed that $\mathrm{AD}$ is caused by more than a single factor. Two of the main factors cited include the presence of dense extracellular deposits of amyloid and phosphorylated tau

CONTACT Filipa V. M. Silva, filipavinagresilva@gmail.com

This article has been republished with minor changes. These changes do not impact the academic content of the article. 
protein that form neurofibrillary tangles (Babic 1999). 'Cholinergic hypothesis' is another explanation for the progression of $\mathrm{AD}$, the main approach to the treatment of $\mathrm{AD}$. It is believed that cognitive ability is directly related to the level of acetylcholine (ACh) in the brain (Talesa 2001). The loss of ACh is reduced by simulating the cholinergic receptors or prolonging the availability of ACh release. This is achieved by inhibiting ACh hydrolysis caused by acetylcholinesterase (AChE) enzyme (Babic 1999). The AChE inhibitors remain the mainstay in the treatment of $\mathrm{AD}$.

Another brain enzyme called butyrylcholinesterase (BChE) is also believed to contribute to $\mathrm{AD}$ progression, especially in the later stages of the disease. The level of AChE may decline by up to $85 \%$ in the later stages of the disease, while $\mathrm{BChE}$ becomes the predominant cholinesterase in brain (Orhan et al. 2011). BChE is approximately 10\% of the total cholinesterase enzyme in a normal human brain and the increase of this enzyme or its activity may also cause the formation of senile plaques (Schelterns and Feldman 2003). The inhibition of BChE activity by BChE inhibitors may retard this process. These inhibitors are especially useful to treat moderate or advanced stages of $\mathrm{AD}$, and can be used as a specific $\mathrm{BChE}$ inhibitor or for dual inhibition functions to also reduce the hydrolysis of the brain ACh (Tappayuthpijarn et al. 2012).

As of now, there are yet to develop therapeutic interventions to completely cure AD or to reverse the disease's progression. Most existing treatments treat $\mathrm{AD}$ symptomatically and provide temporary relief for $\mathrm{AD}$ patients. Current therapies have been shown to increase the quality of life of $\mathrm{AD}$ patients, such as improving their mood, increasing their social interaction, and diminishing memory loss and confusion (Herrmann et al. 2011). According to the Alzheimer's Association (2020), there are five approved medications, three of which are cholinesterase inhibitors (donepezil, galanthamine, rivastagmine) usually prescribed for early to moderate stages. The other 2 are N-methyl-Daspartate (NMDA), a receptor antagonist (memantine), and a drug that combines memantine and donepezil, both are prescribed for moderate-to-severe cases. New approaches in $\mathrm{AD}$ treatment of are being developed. Among them is one based on $\beta$-secretase inhibitors. This type of treatment is thought to be an ideal therapeutic target by blocking the production of $\beta$-amyloid protein (a major component of the amyloid plaque), which is believed to play an early and crucial role in all cases of AD (Schelterns and Feldman 2003).

Oxidative stress has been known to be the main cause of many diseases. This includes several age-related diseases such as diabetes, autoimmune and central nervous system-type diseases (Khansari et al. 2009). Oxidative damage is thought to be associated with the two main pathological hallmarks of AD (senile plaques and neurofibrillary tangles). Tayeb et al. (2012) emphasised the importance of antioxidants such as Vitamins E and C as possible therapeutic approaches for dementia.

Phytomedicines have emerged as an alternative or complement to standard approved drugs in the pharmaceutical field, as they cause fewer side effects, and present multi-functional properties being procholinergic, antioxidant, anti-amyloid, and anti-inflammatory. In addition, phytomedicines are less toxic and can have multiple synergistic effects (Anekonda and Reddy 2005), such as enhanced cognitive and cholinergic functions.

Despite the abundant biodiversity of New Zealand, only a handful of its endemic plants have been commercially exploited. New Zealand constitutes a distinctive botanic region, with almost 1500 species of higher plants that are endemic to the country (Brooker and Cooper 1961). A previous study revealed the inhibitory potential of extracts obtained 
from several New Zealand plants against multiple enzymes of clinical significance (Kellam et al. 1992). Despite this, very few pharmacological studies have been conducted on native plants of New Zealand, especially on those related to the treatment of AD.

In this study, 15 small trees and bushes which are traditionally used in New Zealand by Māori for treatment of different ailments (Riley, 1994) were investigated for their potential role in the development of therapeutic agents for $\mathrm{AD}$. Two different extracts prepared with methanol and ethyl acetate from selected plants were screened for the inhibition of AChE, $\mathrm{BChE}$ and beta-secretase. In addition the antioxidant potential of the extracts was also investigated using the DPPH radical scavenging activity (RSA) method and expressed in terms of $\mathrm{IC}_{50}$ concentration.

\section{Materials and methods}

\section{Plants and preparation of extracts}

Table 1 shows the scientific and common names of the 15 plants (bushes and small trees endemic to New Zealand) selected for this study, as there is prior empirical knowledge from Māori people of the traditional plants uses for mental/memory-related issues. The following species and parts were tested: Weinmannia racemosa (bark), Kunzea ericoides (leaves), Pseudowintera colorata (leaves), Leptospermum scoparium (leaves), Schefflera digitata (leaves), Myrsine australis (leaves), Aristotelia serrata (leaves), Pomaderris kumeraho (leaves), Acaena microphylla (leaves), Phormium tenax (rhizomes), Geniostoma ligustrifolium (leaves), Melicytus ramiflorus (leaves), Hebe stricta (leaves), Macropiper excelsium (leaves), Coprosma robusta (leaves). Plant materials harvested during late Spring/ Summer in 2013 were supplied and identified by Fred Allen, an expert with a profound

Table 1. Selection of New Zealand trees/bushes investigated in this study: Scientific names, common Mãori names and part of the plant used to produce the methanol and ethyl acetate extracts*.

\begin{tabular}{|c|c|c|c|c|}
\hline Scientific name & Local name & $\begin{array}{c}\text { Part of plant } \\
\text { used }\end{array}$ & Type of plant & Scientist \\
\hline $\begin{array}{l}\text { Weinmannia } \\
\text { racemosa }\end{array}$ & kāmahi & bark & tree & $\begin{array}{l}\text { Linnaeus C. von filius, } \\
1782\end{array}$ \\
\hline Kunzea ericoides & kānuka & leaves & tree & Richard A, 1832 \\
\hline $\begin{array}{l}\text { Pseudowintera } \\
\text { colorata }\end{array}$ & horopito, pepper tree & leaves & small tree & Raoul E, 1844 \\
\hline $\begin{array}{l}\text { Leptospermum } \\
\text { scoparium }\end{array}$ & mānuka, tea tree & leaves & tree & $\begin{array}{l}\text { Forster JR and Forster G, } \\
1776\end{array}$ \\
\hline Schefflera digitata & $\begin{array}{l}\text { patete, umbrella tree, } \\
\text { seven finger }\end{array}$ & leaves & tree & $\begin{array}{l}\text { Forster JR and Forster G, } \\
1776\end{array}$ \\
\hline Myrsine australis & matipo & leaves & shrub or small tree & Richard A, 1832 \\
\hline Aristotelia serrata & makomako & leaves & small tree & Oliver WRB, 1921 \\
\hline Pomaderris kumeraho & kumarahou & leaves & shrub & Cunningham A, 1839 \\
\hline Acaena microphylla & piripiri & leaves & small herb & Hooker JD, 1853 \\
\hline Phormium tenax & harakeke, flax & rhizomes & $\begin{array}{l}\text { evergreen perennial } \\
\text { plant }\end{array}$ & $\begin{array}{l}\text { Forster JR and Forster G, } \\
1776\end{array}$ \\
\hline $\begin{array}{l}\text { Geniostoma } \\
\text { ligustrifolium }\end{array}$ & hangehange & leaves & shrub & Cunningham A, 1838 \\
\hline Melicytus ramiflorus & māhoe & leaves & small tree & $\begin{array}{l}\text { Forster JR and Forster G, } \\
1776\end{array}$ \\
\hline Hebe stricta & koromiko & leaves & herb & Jussieu AL de, 1789 \\
\hline Macropiper excelsum & kawakawa & leaves & small tree & Forster G, 1786 \\
\hline Coprosma robusta & karamu & leaves & bushy shrub & Raoul E, 1844 \\
\hline
\end{tabular}

*Information extracted from the internet: Mãori Plant Use, https://maoriplantuse.landcareresearch.co.nz 
knowledge of New Zealand native plants/trees/bushes, from Kiwi Plants Ltd (Member of Te Paepae Matua mo Te Rongoa, Nga Ringa Whakahaere o te iwi Māori, and Natural Products New Zealand). The plant samples, purchased as dried flakes at moisture content lower than $5 \%$, were further dried in the dark inside an oven at $30^{\circ} \mathrm{C}-40^{\circ} \mathrm{C}$ for $48 \mathrm{~h}$ to remove possible moisture. Then, the dried materials were ground before being vacuum-sealed and stored in a dark condition at room temperature prior to extraction.

Soxhlet extraction uses higher temperature than maceration which can affect the phytochemical composition of plant extracts leading to decomposition of many secondary metabolites as well as the formation of artefacts. However, Soxhlet was the method chosen to prepare the extracts due to the following: higher extraction yield, ease of extraction with less time required for extraction, no filtration required after extraction, the ability to pre-evaporate for preparing the dried crude extract, preliminary results showing higher inhibition of enzymes by some of the extracts prepared using Soxhlet extraction compared to maceration at room temperature. Ten grams of finely ground sample was extracted with $125 \mathrm{~mL}$ of either methanol or ethyl acetate using a Soxhlet extractor (Extraction System B-811, BÜCHI Labortechnik AG, Flawil, Switzerland). Based on preliminary works, the optimised period for extraction of $10 \mathrm{~g}$ ground sample is 12 cycles (40-60 min). The ideal extraction temperature for each solvent was set according to their boiling points. The solution was filtered and concentrated by using a rotary evaporator (Rotavapor R-215, BÜCHI Labortechnik AG, Flawil, Switzerland). The concentrated extracts were further evaporated to dryness via air-drying at ambient temperature for $24 \mathrm{~h}$. All residues were stored in the dark at $-70^{\circ} \mathrm{C}$ prior to analysis.

\section{Chemicals}

Methanol (megh3041) and ethyl acetate (etjhH078) were of chromatography grade and obtained from ECP (ECP laboratory research and chemicals, New Zealand). Phosphate buffer powder $\left(\mathrm{KH}_{2} \mathrm{PO}_{4}\right)(\mathrm{P} 7994)$, potassium hydroxide $(\mathrm{KOH})(\mathrm{P} 1767), 5,5$ '-dithiobis(2-nitrobenzoic acid) (DTNB) (D218200), sodium hydrogen carbonate $\left(\mathrm{NaHCO}_{3}\right)$ (S5761), acetylthiocholine iodide substrate (ATchI) (A5751), butyrylthiocholine iodine (BTchI) (20820), acetylcholinesterase from human erythrocytes (AChE) (C0663), butyrylcholinesterase human serum (BChE) (B4186), dimethyl sulfoxide (DMSO) (41641), donepezil (D6821), eserine (E8375), quercetin (Q4951), ascorbic acid (PHR1008) and 2,2-diphenyl-1-picrylhydrazyl (DPPH) (D9132) were purchased from Sigma-Aldrich (NZ). Beta-secretase (BACE1) assay kit from PanVera Co. (USA) (P2985) was used to test the inhibition of BACE1. Donepezil is an approved Alzheimer medicine with potent AChE enzyme inhibition capacity) and was used as a control for AChE inhibition. Eserine (phystogmine), quercetin, and ascorbic acid were used as positive controls for BChE inhibition, beta-secretase inhibition and antioxidant activity assays, respectively. Deionised water was used for all experiments.

\section{Determination of enzyme inhibition and $I C_{50}$ concentrations}

\section{Acetylcholinesterase and butyrylcholinesterase inhibition assays}

The assay for measuring AChE activity was measured by the microplate assay using Ellman's colorimetric method and modified by Rauter et al. (2007). Buffers were prepared 
as follows: $0.1 \mathrm{M}$ phosphate buffer was freshly before each analysis $\left(136.1 \mathrm{mg}\right.$ of $\mathrm{KH}_{2} \mathrm{PO}_{4}$ in $10 \mathrm{~mL}$ water, adjusted at $\mathrm{pH} 8.0$ with $\mathrm{KOH}$ ); $0.01 \mathrm{M}$ DTNB solution (3.96 mg DTNB in $1 \mathrm{~mL}$ water containing $1.5 \mathrm{mg}$ sodium hydrogen carbonate). $0.022 \mathrm{M}$ ATchI solution (6.4 mg ATchI in $1 \mathrm{~mL}$ water); $1.32 \mathrm{Unit} / \mathrm{mL} \mathrm{AChE}$ solution (4.4 mg of AChE enzyme $(10 \mu \mathrm{L}, 1.02041 \mathrm{U})$ in $1.0 \mathrm{~mL}$ buffer at $\mathrm{pH} 8.0$.

For the enzymatic analysis, dry plant extracts in solid or paste form produced were initially dissolved in DMSO and diluted in distilled water to a concentration of $44 \mathrm{mg} /$ $\mathrm{mL}$ to test a final extract concentration of $1000 \mu \mathrm{g} / \mathrm{mL}$. Donepezil is an approved drug that inhibits AChE and was used as control. The compound was initially dissolved in DMSO and diluted in distilled water to $44 \mathrm{mg} / \mathrm{mL}$ to give a final test concentration of $1000 \mu \mathrm{g} / \mathrm{mL}$. A blank test without plant extract demonstrated no inhibition of DMSO at the highest concentration used (12.5\%).

The assay was achieved by adding $5 \mu \mathrm{L}$ of plant sample extract, $200 \mu \mathrm{L}$ phosphate buffer, $5 \mu \mathrm{L}$ of AChE enzyme, and $5 \mu \mathrm{L}$ DTNB reagent in a 96-well microplate kept for $15 \mathrm{~min}$ at $30^{\circ} \mathrm{C}$. Then, $5 \mu \mathrm{L}$ of ATchI substrate solution was added to the mixture to start the enzymatic reaction. Absorbances were determined using a microplate reader operated under controlled temperature (EnSpire Multimode Plate Reader) at $405 \mathrm{~nm}$ for every $45 \mathrm{~s}$, 6 times consecutively at a controlled temperature of $30^{\circ} \mathrm{C}$. For each extract the experiments were done in triplicate and the enzyme inhibition was calculated using equation 1 :

$$
\text { Inhibition }(\%)=100-\left[\left(\frac{V_{\text {extract }}}{V_{\max }}\right) \times 100\right]
$$

where $V_{\text {extract }}$ is the rate of change in the absorbance of the test containing plant extract ( $\Delta a b s / \Delta$ time) and $V_{\max }$ is the maximum rate of change in the absorbance of the blank sample without any inhibitor.

Regarding $\mathrm{BChE}$, buffer and solutions were freshly prepared as explained for $\mathrm{AChE}$ before each experiment. $0.44 \mathrm{U} / \mathrm{mL}$ BChE solution (2.9762 mg BChE enzyme was dissolved in 6.746 mL buffer at pH 8.0); 0.022 M BTchI solution (7.0 mg BTchI was dissolved in $1 \mathrm{~mL}$ water). The solid or paste plant extracts were dissolved with DMSO followed by distilled water to $44 \mathrm{mg} / \mathrm{mL}$, to obtain a final concentration of $1000 \mu \mathrm{g} / \mathrm{mL}$. BChE inhibition assay was similar to AChE and absorbances were also measured in the same microplate reader. A solution consisted of $200 \mu \mathrm{L}$ buffer, $5 \mu \mathrm{l}$ BChE enzyme, $5 \mu \mathrm{L}$ DTNB and $5 \mu \mathrm{L}$ plant extracts at the concentration of $44 \mathrm{mg} / \mathrm{mL}$ were mixed and kept for $15 \mathrm{~min}$ at $30^{\circ} \mathrm{C}$ in a temperature controlled water bath. Subsequently, $5 \mu \mathrm{L}$ of BTchI substrate solution was added to the mixture to initiate the enzymatic reaction. Absorbances were taken at $410 \mathrm{~nm}$ using the microplate reader at $45 \mathrm{~s}$ intervals 13 times under regulated temperature of $30^{\circ} \mathrm{C}$. The experiments were run in triplicate. The absorbances were used to calculate enzymatic inhibition using equation 1 . Eserine is an approved drug used as a control for BChE inhibition and was tested at a final concentration of $10 \mu \mathrm{g} / \mathrm{mL}$.

\section{Beta-secretase inhibition assay}

The beta-secretase inhibition procedure was carried out in accordance to the method provided by the manufacturer (PanVera Co., USA) with modifications (Lee et al. 2005). The beta-secretase assay kit allows for the detection of beta secretase activity in biological samples. The procedures involved in this assay were performed in a 96 well plates. 
Buffers were freshly prepared before each experiment, the preparation are as follows: $1.0 \mathrm{Unit} / \mathrm{mL}(500 \mu \mathrm{M})$ of BACE1 enzyme - $(50 \mathrm{mM}$ Tris at $\mathrm{pH} 7.5,10 \%$ glycerol $)$ was diluted with BACE1 assay buffer $(50 \mathrm{mM}$ sodium acetate at $\mathrm{pH} 4.5)$ to produce $3 \mathrm{X}$ working solution. A total of minimum of $4.0 \mathrm{~mL}$ of this enzyme solution was prepared.

A $750 \mathrm{nM}$ BACE1 substrate - The initial concentration of BACE1 substrate (Rh-EVNLDAEFK-Quendcher in $50 \mathrm{mM}$ ammonium bicarbonate) was $75 \mu \mathrm{M}$ (300X). A $40 \mu \mathrm{L}$ of BACE1 substrate $(75 \mu \mathrm{M})$ was added to $3960 \mu \mathrm{L}$ of BACE1 assay buffer (50 mM sodium acetate at $\mathrm{pH} 4.5$ ) to prepare a $750 \mathrm{mM}$ stock (3X). The substrate was stored in an amber container and was added directly to the wells.

Test sample $-10 \mu \mathrm{L}$ of plant extract sample and quercetin (the control) were initially dissolved in DMSO and further dissolved in BACE1 assay buffer $(50 \mathrm{mM}$ sodium acetate at $\mathrm{pH}$ 4.5). The concentrations were $2 \mathrm{mg} / \mathrm{mL}$ for plant extract and $0.02 \mathrm{mg} / \mathrm{mL}$ for quercetin, to produce final concentration for the BACE1 assay of $500 \mu \mathrm{g} / \mathrm{mL}$ and $5 \mu \mathrm{g} / \mathrm{mL}$, respectively. The total DMSO in the solution is less than $12.5 \%$ which is within the value specified by the manufacturer. The experiments were done in triplicate.

For the beta-secretase inhibition assay, $10 \mu \mathrm{L}$ BACE1 substrate $(75 \mu \mathrm{M})$ was added to $10 \mu \mathrm{L}$ of extract sample and mixed gently. Later, $10 \mu \mathrm{L}$ of BACE1 enzyme $(1 \mathrm{U} / \mathrm{ml})$ was added to the mixture to start the reaction. The whole arrangement was incubated for $60 \mathrm{~min}$ at room temperature in dark condition. The reaction is stopped by adding $10 \mu \mathrm{L}$ stop buffer solution. The mixture was allowed for excitation at $545 \mathrm{~nm}$ and reading was recorded at $585 \mathrm{~nm}$ emissions. The inhibition ratio is calculated by the following equation (2):

$$
\operatorname{BACE}(\%)=\left[1-\left(\frac{S-S_{o}}{B-B_{o}}\right)\right] \times 100
$$

where $S$ is the fluorescence of the tested samples (enzyme, sample solution and substrate) after $60 \mathrm{~min}$ of incubation, $S_{0}$ is the fluorescence of the tested samples at time $0 . B$ is the fluorescence of the blank sample without inhibitor extract/compound (enzyme, assay buffer and substrate) after $60 \mathrm{~min}$ of incubation, and $B_{0}$ is the fluorescence of the blank at time 0 .

\section{$I C_{50}$ concentrations of most active extracts}

$\mathrm{The} \mathrm{IC}_{50}$ (in $\mu \mathrm{g} / \mathrm{ml}$ ) is the plant extract concentration that inhibits $50 \%$ of enzyme activity. The $\mathrm{IC}_{50}$ concentrations were determined for the most inhibitory extracts (and the controls) by performing a nonlinear regression of the enzyme inhibition (\%) against the $\log$ (extract concentration) plot, using GraphPad Prism 6 trial version (GraphPad Software Inc, La Jolla, CA, USA). The results for $\mathrm{IC}_{50}$ were reported as mean and $95 \%$ confidence interval. At least four different concentrations ( $\times 3$ replicates) were tested and used for the regression.

\section{Determination of extracts' antioxidant DPPH radical scavenging activity and $I C_{50}$ concentrations}

The antioxidant activity of plant extracts was determined using free-radical scavenging effect on the 2,2-diphenyl-1-picrylhydrazyl (DPPH) radical with slight modification 
(Rauter et al. 2009). Methanol DPPH solution (100 $\mu \mathrm{M})$ was prepared a day before analysis, to ensure a fully dissolved solution with a stable wavelength measurement. An aliquot of $10 \mu \mathrm{L}$ plant extract was mixed with $190 \mu \mathrm{L}$ of DPPH solution in a clear 96-well microplate. The mixture was shaken vigorously before being kept in dark at room temperature for $40 \mathrm{~min}$. All the test solutions were measured at $517 \mathrm{~nm}$ using a microplate reader (EnSpire Multimode Plate Reader). The results were shown as percentage of DPPH radical scavenging activity (RSA), and the values represented the radical scavenging capacity of the extracts. The experiments were run in triplicate. The percentage of $\mathrm{DPPH}$ activity is calculated as follows:

$$
\text { DPPH RSA }(\%)=\frac{A b s_{\text {blank }}-A b s_{\text {extract }}}{A b s_{\text {blank }}} \times 100 \%
$$

The $A b s_{\text {blank }}$ is the absorbance of DPPH solution without plant extract while $A b s_{\text {extract }}$ is the absorbance of the sample containing the extract, which was registered after $40 \mathrm{~min}$. Ascorbic acid was used as a standard antioxidant for DPPH RSA. Then, the $\mathrm{IC}_{50}$ values (in $\mu \mathrm{g} / \mathrm{mL}$ ) were estimated from the RSA results obtained for four different extract concentrations, as $\mathrm{IC}_{50}$ is the plant extract concentration (or ascorbic acid, control) which causes $50 \%$ DPPH RSA. For each plant extract, the $\mathrm{IC}_{50}$ value was determined through a nonlinear regression of the plot RSA (\%) against the log (extract concentration) using GraphPad Prism six trial version (GraphPad Software Inc, La Jolla, CA, USA). The results for $\mathrm{IC}_{50}$ were reported as mean and $95 \%$ confidence interval.

\section{Results and discussion}

\section{Enzyme inhibition by the New Zealand plant extracts}

The AChE, BChE and beta-secretase (BACE1) inhibitions of 30 trees/bushes extracts are summarised in Table 2. The detection limit of this method is about $5 \%$, the enzyme inhibition variability/error, and so $<5 \%$ indicates no inhibition or residual inhibition. The methanol and ethyl acetate extracts of 15 species were analysed at $1000 \mu \mathrm{g} / \mathrm{mL}$ for $\mathrm{AChE}$ and BChE, and at a concentration of $500 \mu \mathrm{g} / \mathrm{mL}$ for BACE1. Extracts from three plants were very active against the three enzyme systems and seem promising in terms of Alzheimer's disease application: Weinmannia racemosa, Kunzea ericoides and Pseudowintera colorata with inhibitions above $50 \%$ for all enzymes tested. W. racemosa and K. ericoides presented higher inhibitions above $90 \%$ for AChE-BChE and BACE1, respectively. The bark decoction of $W$. racemosa was traditionally used to treat abdominal and thoracic pains (Brooker et al. 1987). It contains up to $20 \%$ of tannins and some traces of catechin (Cambie 1976). Tannic acid, which is a form of tannin has been shown to have strong inhibition against both AChE and BChE (Patil et al. 2019; Türkan et al. 2019). The $\mathrm{IC}_{50}$ concentrations of the most active extracts were also determined (presented in Table 3). A low $\mathrm{IC}_{50}$ is desirable as it indicates a lower extract concentration for $50 \%$ enzyme inhibition.

With respect to AChE, 12 species inhibited the enzyme at $1000 \mu \mathrm{g} / \mathrm{mL}$. The most active one was $W$. racemosa $(86 \%-90 \%$ inhibition at $1000 \mu \mathrm{g} / \mathrm{mL})$ which was comparable to the control donepezil at a concentration of $10 \mu \mathrm{g} / \mathrm{mL}$. Then follows Leptospermum scoparium (75\%-88\%), Schefflera digitata (69\%-84\%), K. ericoides (65-77\%) and methanol extract of 
Table 2. Inhibition (\%) of three enzymes related to Alzheimer's disease by methanol and ethyl acetate extracts of $15 \mathrm{New}$ Zealand native trees/bushes: $1000 \mu \mathrm{g} / \mathrm{mL}$ of extract for AChE (acetylcholinesterase) and butyrylcholinesterase (BChE), and $500 \mu \mathrm{g} / \mathrm{ml}$ of extract for beta-secretase (BACE1)*.

\begin{tabular}{|c|c|c|c|c|}
\hline & & \multicolumn{3}{|c|}{ Enzyme inhibition (\%) } \\
\hline & & $\overline{\mathrm{AChE}}$ & $\mathrm{BChE}$ & BACE1 \\
\hline Plant species & Extract concentration & $1000 \mu \mathrm{g} / \mathrm{mL}$ & $1000 \mu \mathrm{g} / \mathrm{mL}$ & $500 \mu \mathrm{g} / \mathrm{mL}$ \\
\hline \multirow[t]{2}{*}{ Weinmannia racemosa (bark) } & Methanol & $90.36 \pm 2.09$ & $97.96 \pm 1.58$ & $56.90 \pm 3.83$ \\
\hline & Ethyl acetate & $85.76 \pm 7.94$ & $100.00 \pm 0.00$ & $38.85 \pm 8.30$ \\
\hline \multirow[t]{2}{*}{ Kunzea ericoides (leaves) } & Methanol & $77.32 \pm 4.93$ & $74.23 \pm 0.85$ & $95.86 \pm 3.29$ \\
\hline & Ethyl acetate & $64.97 \pm 3.75$ & $82.13 \pm 3.08$ & $90.59 \pm 1.05$ \\
\hline \multirow[t]{2}{*}{ Pseudowintera colorata (leaves) } & Methanol & $<5$ & $36.66 \pm 4.33$ & $<5$ \\
\hline & Ethyl acetate & $60.29 \pm 5.02$ & $61.67 \pm 5.93$ & $62.59 \pm 5.94$ \\
\hline \multirow[t]{2}{*}{ Leptospermum scoparium (leaves) } & Methanol & $88.15 \pm 1.12$ & $22.64 \pm 5.94$ & $27.67 \pm 1.39$ \\
\hline & Ethyl acetate & $75.49 \pm 2.13$ & $<5$ & $43.77 \pm 1.96$ \\
\hline \multirow[t]{2}{*}{ Schefflera digitata (leaves) } & Methanol & $68.67 \pm 1.14$ & $71.42 \pm 0.59$ & $37.16 \pm 7.01$ \\
\hline & Ethyl acetate & $84.41 \pm 5.71$ & $88.32 \pm 5.59$ & $<5$ \\
\hline \multirow[t]{2}{*}{ Myrsine australis (leaves) } & Methanol & $51.26 \pm 0.64$ & $57.60 \pm 1.94$ & $16.17 \pm 1.34$ \\
\hline & Ethyl acetate & $59.06 \pm 6.60$ & $71.18 \pm 5.48$ & $8.76 \pm 4.55$ \\
\hline \multirow{2}{*}{ Aristotelia serrata (leaves) } & Methanol & $50.23 \pm 1.95$ & $98.42 \pm 0.06$ & $8.33 \pm 3.27$ \\
\hline & Ethyl acetate & $36.05 \pm 4.95$ & $94.35 \pm 0.12$ & $14.82 \pm 4.81$ \\
\hline \multirow[t]{2}{*}{ Pomaderris kumeraho (leaves) } & Methanol & $73.11 \pm 3.14$ & $63.73 \pm 1.76$ & $28.42 \pm 2.03$ \\
\hline & Ethyl acetate & $14.95 \pm 3.48$ & $38.64 \pm 3.28$ & $15.68 \pm 3.26$ \\
\hline \multirow[t]{2}{*}{ Acaena microphylla (leaves) } & Methanol & $31.51 \pm 4.21$ & $10.64 \pm 3.37$ & $4.19 \pm 3.74$ \\
\hline & Ethyl acetate & $55.69 \pm 3.98$ & $95.36 \pm 0.24$ & $18.54 \pm 6.63$ \\
\hline \multirow{2}{*}{ Phormium tenax (rhizomes) } & Methanol & $28.82 \pm 1.53$ & $14.90 \pm 1.73$ & $32.34 \pm 3.89$ \\
\hline & Ethyl acetate & $46.83 \pm 2.96$ & $<5$ & $31.44 \pm 3.08$ \\
\hline \multirow[t]{2}{*}{ Geniostoma ligustrifolium (leaves) } & Methanol & $<5$ & $29.06 \pm 4.21$ & $45.55 \pm 3.55$ \\
\hline & Ethyl acetate & $<5$ & $31.64 \pm 4.35$ & $19.81 \pm 6.50$ \\
\hline \multirow[t]{2}{*}{ Melicytus ramiflorus (leaves) } & Methanol & $<5$ & $<5$ & $<5$ \\
\hline & Ethyl acetate & $<5$ & $49.14 \pm 6.00$ & $<5$ \\
\hline \multirow[t]{2}{*}{ Hebe stricta (leaves) } & Methanol & $<5$ & $20.59 \pm 2.92$ & $<5$ \\
\hline & Ethyl acetate & $<5$ & $<5$ & $<5$ \\
\hline \multirow[t]{2}{*}{ Macropiper excelsum (leaves) } & Methanol & $16.82 \pm 7.62$ & $<5$ & $2.87 \pm 3.95$ \\
\hline & Ethyl acetate & $33.77 \pm 2.82$ & $<5$ & $37.27 \pm 4.68$ \\
\hline \multirow[t]{2}{*}{ Coprosma robusta (leaves) } & Methanol & $22.05 \pm 6.76$ & $<5$ & $<5$ \\
\hline & Ethyl acetate & $46.09 \pm 5.06$ & $<5$ & $24.71 \pm 3.32$ \\
\hline Donepezil $^{\mathrm{a}} 10 \mu \mathrm{g} / \mathrm{mL}$ & & $92.03 \pm 0.33$ & - & - \\
\hline Eserine $^{\mathrm{a}} 10 \mu \mathrm{g} / \mathrm{mL}$ & & - & $89.38 \pm 6.06$ & - \\
\hline Quercetin $^{\mathrm{a}} 5 \mu \mathrm{g} / \mathrm{mL}$ & & - & - & $38.73 \pm 2.71$ \\
\hline
\end{tabular}

*There is a high variability when working with enzymes and it is difficult to measure any inhibition below 5\%, as the error is of that magnitude. Inhibition values are mean \pm standard deviation of triplicate experiments.

${ }^{a}$ Controls donepezil and eserine are approved drugs used as medicines for Alzheimer's disease which inhibit AChE and $B C h E$, respectively. Quercetin is an inhibitor of BACE1. The inhibition values are included to indicate results of reference compounds. As references/controls are pure chemicals, inhibitions are expected to be much higher than in a plant extract.

Pomaderris kumeraho (73\%). L. scoparium commonly known as manuka is already a bush of already great commercial importance in the New Zealand honey production and

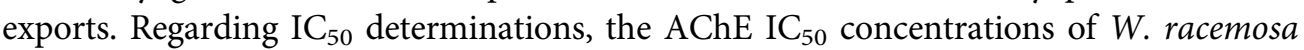
bark extract were $8.09 \mu \mathrm{g} / \mathrm{mL}$ for the methanol extract and $11.25 \mu \mathrm{g} / \mathrm{mL}$ for the ethyl acetate extract. The methanol extract of $L$. scoparium presented an $\mathrm{IC}_{50}$ concentration of $65.25 \mu \mathrm{g} / \mathrm{mL}$, notable for a crude extract. Geniostoma ligustrifolium, Melicytus ramiflorus and Hebe stricta had no inhibition effect over AChE enzyme. The inhibitory potential of $L$. scoparium extracts may be attributed to their terpenoid compounds, which was identified from the leaves of L. scoparium (Häberlein and Tschiersch 1994). In a study involving marine products, terpenoid compounds have been shown to have partial inhibition of AChE enzyme (Beedessee et al. 2013). In addition, manuka (or tea tree), the common name for L. scoparium, is already a commercial culture abundant 
Table 3. Acetylcholinesterase (AChE), butyrylcholinesterase (BChE), and beta-secretase (BACE1) IC 50 concentrations and lower/upper limits of $95 \%$ confidence intervals for the methanol and the ethyl acetate extracts of selected New Zealand bushes/trees*.

\begin{tabular}{|c|c|c|c|c|c|c|c|c|c|c|}
\hline \multirow[b]{3}{*}{ Plant species } & \multirow[b]{3}{*}{ Extract } & \multicolumn{3}{|c|}{$\mathrm{AChE}$} & \multicolumn{3}{|c|}{$\mathrm{BChE}$} & \multicolumn{3}{|c|}{ Beta-secretase } \\
\hline & & \multirow[b]{2}{*}{$\mathrm{I} C_{50}(\mu \mathrm{g} / \mathrm{mL})$} & \multicolumn{2}{|c|}{ 95\% confidence interval } & \multirow[b]{2}{*}{$\mathrm{IC}_{50}(\mu \mathrm{g} / \mathrm{mL})$} & \multicolumn{2}{|c|}{ 95\% confidence interval } & \multirow[b]{2}{*}{$\mathrm{IC}_{50}(\mu \mathrm{g} / \mathrm{mL})$} & \multicolumn{2}{|c|}{ 95\% confidence interval } \\
\hline & & & Lower limit & Upper limit & & Lower limit & Upper limit & & Lower limit & Upper limit \\
\hline \multirow{2}{*}{ Weinmannia racemosa (bark) } & Methanol & 8.094 & 7.129 & 9.190 & 37.07 & 33.48 & 41.04 & ND & & \\
\hline & Ethyl acetate & 11.25 & 8.21 & 15.41 & 24.88 & 23.25 & 26.62 & ND & & \\
\hline \multirow[t]{2}{*}{ Kunzea ericoides (leaves) } & Methanol & 215.4 & 171.7 & 270.2 & 361.6 & 320.3 & 408.2 & 29.05 & 26.00 & 32.46 \\
\hline & Ethyl acetate & 687.2 & 575.0 & 821.4 & 464.9 & 375.2 & 576.2 & 36.40 & 29.80 & 44.46 \\
\hline \multirow[t]{2}{*}{ Leptospermum scoparium (leaves) } & Methanol & 65.25 & 54.97 & 77.45 & ND & & & ND & & \\
\hline & Ethyl acetate & 218.5 & 200.1 & 238.6 & ND & & & ND & & \\
\hline \multirow[t]{2}{*}{ Schefflera digitata (leaves) } & Methanol & 439.8 & 401.9 & 481.4 & 168.0 & 135.0 & 209.0 & ND & & \\
\hline & Ethyl acetate & 270.5 & 227.7 & 321.4 & 25.38 & 18.09 & 35.59 & ND & & \\
\hline \multirow[t]{2}{*}{ Aristotelia serrata (leaves) } & Methanol & ND & & & 24.50 & 19.68 & 30.49 & ND & & \\
\hline & Ethyl acetate & ND & & & 67.88 & 63.66 & 72.38 & ND & & \\
\hline Donepezil (standard) & & 0.7570 & 0.6317 & 0.9071 & ND & & & ND & & \\
\hline Eserine (standard) & & ND & & & 0.9438 & 0.8573 & 1.039 & ND & & \\
\hline Quercetin (standard) & & ND & & & ND & & & 5.691 & 4.530 & 7.150 \\
\hline
\end{tabular}

ND

ND

${ }^{*}$ The $\mathrm{IC}_{50}$ is the concentration of plant extract $(\mu \mathrm{g} / \mathrm{mL})$ which inhibited $50 \%$ of enzyme activity, and was estimated by non-linear regression of the curve enzyme inhibition vs. log concentration of extract. The values in italic are the $95 \%$ confidence interval lower and upper limits. Lower $\mathrm{IC}_{50}$ values indicate more inhibition capacity of the extract. Donepezil, eserine and quercetin are standard compounds inhibitory of $\mathrm{AChE}, \mathrm{BChE}$ and beta-secretase, respectively; $\mathrm{ND}=$ not determined. 
across New Zealand and mostly cultivated for the manuka honey production, known worldwide by its medicinal properties.

Regarding BChE, all the extracts demonstrate some level of BChE inhibitory activity at $1000 \mu \mathrm{g} / \mathrm{mL}$ except for Macropiper excelsum and Coprosma robusta. The inconsistency between $\mathrm{AChE}$ and $\mathrm{BChE}$ inhibition suggest that these extracts may react with the enzymes in a different way (Orhan et al. 2004). Similar to AChE the most powerful plant for BChE inhibition was $W$. racemosa $(98 \%-100 \%$ inhibition at $1000 \mu \mathrm{g} / \mathrm{mL}$, $\left.\mathrm{IC}_{50}=24.88 \mu \mathrm{g} / \mathrm{mL}-37.07 \mu \mathrm{g} / \mathrm{mL}\right)$ and Aristotelia serrata $(94 \%-98 \%$ inhibition at $1000 \mu \mathrm{g} / \mathrm{mL}, \mathrm{IC}_{50, \text { methanol }}=24.50 \mu \mathrm{g} / \mathrm{mL}$ ). The extract of $A$. serrata had been previously demonstrated to contain major component of aristoteline, with some trace of aristotelinone and serretoline, a type of alkaloids (Bick et al. 1980). Since most of the AChE inhibitors are known to contain nitrogen (Orhan et al. 2004), the high BChE inhibitory activity in this extract may be related to its rich alkaloidal content. Following in BChE inhibition was S. digitata $\left(71 \%-88 \%, \mathrm{IC}_{50}\right.$, ethyl acetate $\left.=25.38 \mu \mathrm{g} / \mathrm{mL}\right)$ and $K$. ericoides $(74 \%-82 \%)$, Myrsine australis (58\%-71\%). Curiously, the ethyl acetate extract of Acaena microphylla presented 95\% inhibition while the methanol extract of the same plant only showed $11 \%$ inhibition. One possible explanation is that at a concentration of $1000 \mu \mathrm{g} / \mathrm{mL}$, some of the extracts behave inconsistently due to their nature such as solubility in solvent and final test solution. Due to this, enzymatic testing at a lower concentration (eg $500 \mu \mathrm{g} / \mathrm{mL}$ ) would be preferable in this case.

For beta-secretase (BACE1) K. ericoides, locally known as kanuka was found to be very inhibitory $(91 \%-96 \%$ inhibition at $500 \mu \mathrm{g} / \mathrm{mL})$ presenting $\mathrm{IC}_{50}$ values of $29.05 \mu \mathrm{g} / \mathrm{mL}$ for the methanol extract and $36.40 \mu \mathrm{g} / \mathrm{mL}$ for the ethyl acetate extract. A previous study has reported a major component of glycoside flavonoids presence in this plant (Wyatt et al. 2005), and might be the component responsible for the inhibition of BACE1. Flavonoids were shown to directly inhibit BACE1, in particular four flavonols (myricetin, quercetin, kaempherol and morin) and one flavone compound (apigenin) (Sathya et al. 2012). $W$. racemosa and $P$. colorata presented less inhibition (57\%-63\%) of BACE1. All the other plants presented some degree of inhibition, except $M$. ramiflorus and $H$. stricta with no inhibition $(<5 \%)$.

\section{Antioxidant activity}

The antioxidant activity of methanol and ethyl acetate extracts at several concentrations was assessed by DPPH test. This method measures the hydrogen atom or electron donor capacity of the extracts by scavenging the stable free radical of $\mathrm{DPPH}$, and result is the percentage DPPH radical scavenging activity (RSA, \%) (Equation 3). Table 4 shows the results expressed in terms of $\mathrm{IC}_{50}$, the plant extract concentrations $(\mu \mathrm{g} / \mathrm{mL})$ that causes $50 \%$ of RSA. A low $\mathrm{IC}_{50}$ value is preferable as it represents good RSA, thus good antioxidant activity. The $R^{2}$ for the regression lines of RSA response vs extract concentration $(\mu \mathrm{g} / \mathrm{mL})$ for all the plant extracts are between $72 \%-99 \%$, and the $\mathrm{IC}_{50}$ extract concentrations were estimated from the dose-response lines. The results presented in Table 4 show that all the plant extracts analysed contained good levels of antioxidant capacity. The highest antioxidant activity was identified on methanol extract of A. serrata $(2.34 \mu \mathrm{g} / \mathrm{mL})$. In total, seven extracts exhibited greater inhibition than ascorbic acid, a standard antioxidant used as a control $(12.01 \mu \mathrm{g} / \mathrm{mL})$. These include both extracts 
Table 4. Antioxidant activity $\left(\mathrm{IC}_{50}\right)$ of the methanol and ethyl acetate extracts of selected New Zealand trees/bushes*.

\begin{tabular}{llr}
\hline & \multicolumn{2}{c}{$\mathrm{IC}_{50}(\mu \mathrm{g} / \mathrm{ml})$} \\
\cline { 2 - 3 } Plant species & \multicolumn{1}{c}{ Methanol extract } & Ethyl acetate extract \\
\hline Weinmannia racemosa (bark) & $5.607(4.601-6.833)$ & $5.866(4.848-7.098)$ \\
Aristotelia serrata (leaves) & $2.345(0.7931-6.935)$ & $14.81(10.57-20.76)$ \\
Hebe stricta (leaves) & $8.263(6.486-10.53)$ & $9.914(6.109-16.09)$ \\
Kunzea ericoides (leaves) & $9.579(6.702-13.69)$ & $29.59(27.38-31.99)$ \\
Pomaderris kumeraho (leaves) & $9.672(7.974-11.73)$ & $31.81(28.85-35.07)$ \\
Schefflera digitata (leaves) & $24.67(21.97-27.70)$ & $40.18(38.56-41.86)$ \\
Leptospermum scoparium (leaves) & $17.32(16.27-18.43)$ & $72.15(66.27-78.54)$ \\
Myrsine australis (leaves) & $48.63(47.04-50.27)$ & $50.95(48.64-53.38)$ \\
Phormium tenax (rhizomas) & $55.18(49.39-61.65)$ & $33.30(27.82-39.86)$ \\
Pseudowintera colorata (leaves) & $38.78(36.31-41.41)$ & $94.6(85.33-104.9)$ \\
Acaena microphylla (leaves) & $17.96(14.03-22.99)$ & $253.3(170.7-375.9)$ \\
Macropiper excelsum (leaves) & $79.46(75.04-84.14)$ & $119.3(109.0-130.6)$ \\
Coprosma robusta (leaves) & $120.4(108.8-133.3)$ & $138.5(123.5-155.3)$ \\
Melicytus ramiflorus (leaves) & $310.9(243.1-397.7)$ & $178.6(160.3-199.0)$ \\
Geniostoma ligustrifolium (leaves) & $128.4(120.3-137.1)$ & $680.4(459.0-1009)$ \\
Ascorbic acid (control) & $12.01(10.23-14.11)$ & \\
\hline
\end{tabular}

${ }^{*} \mathrm{C}_{50}$ is the concentration of plant extract $(\mu \mathrm{g} / \mathrm{ml})$ needed to reduce the DPPH scavenging activity to $50 \%$. The values in parenthesis are the $95 \%$ confidence interval lower and upper limits. Lower $\mathrm{IC}_{50}$ values indicate more antioxidant capacity of the extract. Ascorbic acid is a standard antioxidant used as a control.

of $H$. stricta and $W$. racemosa, and the methanol extracts of $A$. serrata, K. ericoides, $P$. kumeraho. The excellent antioxidant potential in $A$. serrata may be explained by the presence of the main alkaloids, aristoteline, and other minor indole alkaloids such as aristotelinone and serratoline (Bick et al. 1980). Several chemical compounds have been identified from the roots, stems, and leaves of makomako, the common name of A. serrata. These include the major alkaloid, aristoteline, and other alkaloids such as makomakine, makonine, aristoserratine, and aristoserratenine (Saxton 2009). Flavonoids are another source of natural antioxidants. This type of phenolic compounds has been identified from the leaf extracts of K. ericoides by Wyatt et al. (2005), which identified traces of aglycone and glycoside flavonoids. In a different study conducted with the extracts of L. scoparium, flavonoids and triterpenoids, known antioxidant compounds, were detected. Triterpenoids are considered as nonvolatile terpenoids, the largest group of plant chemicals that range between 15000 and 20000 compounds. A previous study by Liu et al. (2010) found that a triterpenoid compound possessed antioxidant activity after a positive result of this particular compound on ABTS radical test.

In most cases, radical scavenger activity is found to be higher in the methanol extracts than in the ethyl acetate extracts. This is particularly distinctive in A. microphylla which produced an extract with a relatively low $\mathrm{IC}_{50}$ value of $17.96 \mu \mathrm{g} / \mathrm{mL}$ using methanol, as compared to $253.3 \mu \mathrm{g} / \mathrm{mL}$ when extracted with ethyl acetate. The same effect can also be noted in the extracts of M. excelsum, L. scoparium, P. colorata, and G. ligustrifolium. This result may suggest that all the methanol extracts probably contain more flavanones, and flavonoids (Liu et al. 2000; Pinelo et al. 2005; Adewusi and Steenkamp 2011).

\section{Conclusions}

Among the 15 native New Zealand plants analysed in this study, several plants showed inhibition of $\mathrm{AChE}, \mathrm{BChE}$, beta-secretase, and antioxidant activity. W. racemosa bark 
extracts showed effective inhibition of AChE, BChE, and also antioxidant activity. The leaf extracts of L. scoparium (manuka) and K. ericoides (kanuka) were effective inhibitors of $\mathrm{AChE}\left(\mathrm{IC}_{50}=65.25 \mu \mathrm{g} / \mathrm{mL}\right)$ and beta-secretase $\left(\mathrm{IC}_{50}=29.05 \mu \mathrm{g} / \mathrm{mL}\right)$, respectively, which may add to the commercial value of these plants in New Zealand. A limitation of the study is that although most extracts were sourced from the Wellington region in late 2013, the exact time and place of collection of the commercially supplied extracts is unknown and voucher specimens were not retained so it is unclear whether these findings will apply to extracts from the same plants throughout NZ or only in certain regions. Therefore, another interesting topic for further research is to compare the enzyme inhibition of different plant batches from the same location, and to compare enzyme inhibition of plant batches from different locations in New Zealand. Regarding RSA, both extracts of Hebe stricta and W. racemosa, and the methanol extracts of Aristotelia serrata, $K$. ericoides and $P$. kumeraho showed $\mathrm{IC}_{50}$ concentrations lower than the reference ascorbic acid $(<12.0 \mu \mathrm{g} / \mathrm{mL})$.

In conclusion, a few native New Zealand medicinal plants have the potential to be used as alternative treatments or as a complement to usual therapeutics for Alzheimer's disease.

\section{Acknowledgements}

$\mathrm{PhD}$ scholarship by Ministry of Higher Education Malaysia, Government of Malaysia is acknowledged. The authors would like to thank Fred Allen (Kiwi Plants Ltd, New Zealand) for identification of plant material. The laboratory support of our dearest colleague late Dr. Zaid Saleh is acknowledged. Cynthia Gathman for English editing and proofreading of the manuscript.

\section{Disclosure statement}

No potential conflict of interest was reported by the author(s).

\section{Funding}

This work was supported by Ministry of Higher Education Malaysia, Government of Malaysia: [grant number PhD Scholarship ref. 850319-12-5405].

\section{ORCID}

Hafiz Majid (D) http://orcid.org/0000-0002-7258-0425

Filipa V.M. Silva (D) http://orcid.org/0000-0003-4700-2938

\section{References}

Adewusi EA, Steenkamp V. 2011. In vitro screening for acetylcholinesterase inhibition and antioxidant activity of medicinal plants from Southern Africa. Asian Pacific Journal of Tropical Medicine. 4(10):829-835.

Alzheimer's Association. 2020. Medications for memory. Consulted 4th February 2020. https:// www.alz.org/alzheimers-dementia/treatments/medications-for-memory.

Anekonda TS, Reddy PH. 2005. Can herbs provide a new generation of drugs for treating Alzheimer's disease? Brain Research Reviews. 50(2):361-376. 
Babic T. 1999. The cholinergic hypothesis of Alzheimer's disease: a review of progress. Journal of Neurology, Neurosurgery \& Psychiatry. 67(4):558-558.

Beedessee G, Ramanjooloo A, Surnam-Boodhun R, van Soest RW, Marie DE. 2013. Acetylcholinesterase-inhibitory activities of the extracts from sponges collected in Mauritius waters. Chemistry \& Biodiversity. 10(3):442-451.

Bick IRC, Hai MA, Preston NW, Gallagher RT. 1980. Aristotelinone and serratoline: new indole alkaloids from Aristotelia serrata WRB Oliver. Tetrahedron Letters. 21(6):545-546.

Brooker SG, Cambie RC, Cooper RC. 1987. New Zealand medicinal plants. New Zealand: Heinemann Publishers.

Brooker SG, Cooper RC. 1961. New Zealand medicinal plants. Economic Botany. 15(1):1-10.

Cambie RC. 1976. A New Zealand phytochemical register-part III. Journal of the Royal Society of New Zealand. 6(3):307-379.

Gaudreault R, Mousseau N. 2019. Mitigating Alzheimer's disease with natural polyphenols: a review. Current Alzheimer Research. 16(6):529-543.

Häberlein H, Tschiersch KP. 1994. Triterpenoids and flavonoids from Leptospermum scoparium. Phytochemistry. 35(3):765-768.

Herrmann N, Chau SA, Kircanski I, Lanctôt KL. 2011. Current and emerging drug treatment options for Alzheimer's disease. Drugs. 71(15):2031-2065.

Kellam SJ, Tisch MH, Walker JRL. 1992. Screening of New Zealand native plants for enzyme inhibitory activities. New Zealand Journal of Botany. 30:199-203.

Khansari N, Shakiba Y, Mahmoudi M. 2009. Chronic inflammation and oxidative stress as a major cause of age-related diseases and cancer. Recent Patents on Inflammation \& Allergy Drug Discovery. 3(1):73-80.

Lee HJ, Seong YH, Bae KH, Kwon SH, Kwak HM, Nho SK, Kim KA, Hur JM, Lee KB, Kang YH, et al. 2005. $\beta$-Secretase (BACE1) inhibitors from Sanguisorbae Radix. Archives of Pharmacal Research. 28(7):799-803.

Liu FF, Ang CY, Springer D. 2000. Optimization of extraction conditions for active components in Hypericum perforatum using response surface methodology. Journal of Agricultural and Food Chemistry. 48(8):3364-3371.

Liu CH, Yen MH, Tsang SF, Gan KH, Hsu HY, Lin CN. 2010. Antioxidant triterpenoids from the stems of Momordica charantia. Food Chemistry. 118(3):751-756.

Orhan N, Orhan IE, Ergun F. 2011. Insights into cholinesterase inhibitory and antioxidant activities of five Juniperus species. Food and Chemical Toxicology. 49(9):2305-2312.

Orhan I, Şener B, Choudhary MI, Khalid A. 2004. Acetylcholinesterase and butyrylcholinesterase inhibitory activity of some Turkish medicinal plants. Journal of Ethnopharmacology. 91 (1):57-60.

Patil DN, Patil SA, Sistla S, Jadhav JP. 2019. Comparative biophysical characterization: a screening tool for acetylcholinesterase inhibitors. PloS One. 14(5):e0215291.

Pinelo M, Rubilar M, Jerez M, Sineiro J, Núñez MJ. 2005. Effect of solvent, temperature, and solvent-to-solid ratio on the total phenolic content and antiradical activity of extracts from different components of grape pomace. Journal of Agricultural and Food Chemistry. 53 (6):2111-2117.

Rauter AP, Branco I, Lopes RG, Justino J, Silva FV, Noronha JP, Cabrita EJ, Brouard I, Bermejo J. 2007. A new lupene triterpenetriol and anticholinesterase activity of Salvia sclareoides. Fitoterapia. 78(7-8):474-481.

Rauter AP, Martins A, Lopes R, Ferreira J, Serralheiro LM, Araújo ME, Borges C, Justino J, Silva FV, Goulart M, et al. 2009. Bioactivity studies and chemical profile of the antidiabetic plant Genista tenera. Journal of Ethnopharmacology. 122(2):384-393.

Riley M. 1994. Maori Healing and Herbal. Paraparaumu: Viking Sevenseas N.Z. Ltd.

Sathya M, Premkumar P, Karthick C, Moorthi P, Jayachandran KS, Anusuyadevi M. 2012. BACE1 in Alzheimer's disease. Clinica Chimica Acta. 414:171-178.

Saxton JE. 2009. Alkaloids of Aristotelia species. In: Edwin Saxton J, editor. The chemistry of heterocyclic compounds, indoles, part 4: The monoterpenoid indole alkaloids. Chichester: John Wiley and Sons; p. 47-62. Chapter II. 
Schelterns P, Feldman H. 2003. Treatment of Alzheimer's disease; current status and new perspectives. The Lancet Neurology. 2(9):539-547.

Talesa VN. 2001. Acetylcholinesterase in Alzheimer's disease. Mechanisms of Ageing and Development. 122(16):1961-1969.

Tappayuthpijarn P, Sattaponpan C, Sakpakdeecharoen I, Ittharat A. 2012. Cholinesterase inhibitory and antioxidant activities of thai traditional remedies potentially used for Alzheimer's disease. International Journal of East Asian Studies. 17(1):18-25.

Tayeb HO, Yang HD, Price BH, Tarazi FI. 2012. Pharmacotherapies for Alzheimer's disease: beyond cholinesterase inhibitors. Pharmacology \& Therapeutics. 134(1):8-25.

Türkan F, Taslimi P, Saltan FZ. 2019. Tannic acid as a natural antioxidant compound: discovery of a potent metabolic enzyme inhibitor for a new therapeutic approach in diabetes and Alzheimer's disease. Journal of Biochemical and Molecular Toxicology. 33(8):e22340.

Wyatt RM, Hodges LD, Kalafatis N, Wright PF, Wynne PM, Macrides TA. 2005. Phytochemical analysis and biological screening of leaf and twig extracts from Kunzea ericoides. Phytotherapy Research: An International Journal Devoted to Pharmacological and Toxicological Evaluation of Natural Product Derivatives. 19(11):963-970. 